\title{
The Affective Politics of the Precariat: Reconsidering Alternative Histories of Grassroots Worker Organising
}

\author{
Jennifer Jihye Chun, University of Toronto, Canada
}

\begin{abstract}
This article engages with Guy Standing's arguments about the affective politics of the precariat by reflecting on the conditions that facilitate, as well as constrain, the solidaristic transformation of the precariat. After evaluating Standing's Polanyian theory of social change based on assumptions about the destructive tendencies of neo-liberal capitalism and a liberal politics of hope, it offers two critical interventions. First, celebrating the solidaristic traditions of the past industrial era erases historical patterns of labour organising that were quite exclusionary for traditional denizens such as women, non-white immigrants and people of colour in the United States. Second, a top-down approach to solidaristic transformation neglects alternative histories of grassroots worker organising around nonwork social identities and communities. This historical erasure and neglect overlooks how oppressed and socially devalued workers have sought to challenge the fundamental gap between reality and rhetoric under liberal capitalist democracy, a key predicament for long-standing members of the precariat that persists in today's global era of pervasive inequality and precarity.
\end{abstract}

\section{KEY WORDS}

labour politics; precarity; grassroots organising; affective politics

Guy Standing's new book A Precariat Charter: From Denizens to Citizens lays out an ambitious programme for change. Rather than focus solely on the causes of deepening insecurity, injustice and inequality in the current era of global precarity, Standing emphasises that it is time to focus on solutions. "We need a counter-strategy oriented to the needs, aspirations and insecurities of the precariat", says Standing (2014: 93), especially the millions of people denied the rights, recognition and social safety net granted to citizens. Towards this end A Precariat Charter outlines 29 Articles to guide policy makers and civil-society actors who strive to bring about a different world - one in which thriving rather than surviving is the order of the day. Some notable Articles include: the need for a "broader concept of work", including recognising "unpaid care work as work" (Article 1); the creation of a diverse array of collective associations - including but not limited to labour unions that promote the voice, agency, creativity and solidarity of the precariat (Article 5); various strategies to end the discrimination and dehumanisation of migrant workers (Articles 11-15); and a basic income that guarantees the economic security of all people, regardless of age, gender, race, marital status, labour status, disability and other axes of social difference (Article 25).

The emphasis on solutions, rather than problems, is inspired largely by the recent upsurge in popular unrest. From the myriad protests opposing economic austerity in Europe to the Arab Spring 
uprisings to the global Occupy movement, people around the world have taken to the streets in mass defiance of the status quo. For those who have spent the past two decades studying new forms of collective action, especially among the working poor and socially marginalised, the dynamism of such popular movements is no surprise. Much empirical attention has been paid to the creation of alternative strategies and organisational forms for workers in informal and precarious jobs (Fine, 2006; Milkman, 2006; Von Holdt and Webster, 2008; Chun, 2009; Agarwala, 2013; Paret, 2013), as well as the use of creative campaigns and transnational networks to combat sweatshop labour, wage theft, corporate misbehaviour, migrant exploitation and environmental injustice among others (Waterman, 1999; Seidman, 2007; Evans, 2010; Rodriguez, 2010; Anner, 2011; McCallum, 2013). While there are still many obstacles and barriers, these struggles dispel the notion that the so-called precariat are incapable of mobilising politically. They also foster the sense that change is in the air and scholars need to pay attention. Standing (2014: 131) himself states, "A progressive alternative is emerging. The challenge is to find ways of articulating it and to shape a strategy for realizing it".

Calling attention to the progressive horizons of the precariat denotes a marked shift in tone and outlook from Standing's The Precariat. The New Dangerous Class published in 2011 to A Precariat Charter: From Denizens to Citizens published in 2014. In The Precariat, Standing (2011: 19-25) warned of the right-wing populism, fascism and demagoguery that appeal to an angry and alienated precariat as a "dangerous class" that is "at war with itself" and devoid of the relations of trust and mutuality that characterised the associational communities of the past. In contrast, A Precariat Charter is passionately and resolutely optimistic. Not only will the relentless uncertainty over determining the lives and aspirations of the precariat "give way to the realization that the situation is unendurable", but people from more privileged social strata - the salariat and proficians - will no longer tolerate the neo-liberal project's blatant disregard for reciprocity and due process, fostering a "new progressive politics" that can abolish the precariat and restore the principles of social justice (Standing, 2011: 381, 387).

Standing's embrace of a politics of hope in A Precariat Charter may be a significant departure from his earlier treatise, but it raises age-old Marxist questions about how a "class-in-itself" transforms into a "class-for-itself." How exactly do workers subject to multiple forms of subordination and inequality stand up to power, especially when they are subject to the intimidation, punitive policies and institutional violence of the ruling elite? What kinds of aspirational politics and coalitional practices facilitate and sustain collective resistance in the face of ongoing countermovements by capital and neo-liberal states? These are difficult questions to answer, especially in places where we have seen the systematic dismantling of worker power, labour rights and the criminalisation of public assembly. However, Standing's buoyant optimism compels us to contend with these dilemmas in ways that move beyond the "false optimism" akin to Karl Polanyi and his liberal ideas about the "double movement" (Burawoy, 2010).

In this article, I discuss the conditions that facilitate, as well as constrain, the solidaristic transformation of the precariat. I concur with Standing that the affective politics of the precariat that is, the felt and embodied experiences of precaritisation - is an essential entry point for understanding the activation of the precariat as a collective political force. However, I depart from Standing's analysis in three distinct ways. First, I argue that Standing's Polanyian theory of social change based on neo-liberal destruction is flawed. While anger can be a powerful mobilising force, it does not automatically translate into empowered forms of collective agency or cross-class solidarity. Second, Standing's pessimism about the lack of solidaristic traditions for today's precariat is steeped 
in historical amnesia for it celebrates historical patterns of industrial labour organising that were quite exclusionary for long-standing members of the precariat such as women, non-white immigrants and people of colour in the United States. Third, by embracing a top-down approach to social change, Standing ignores the significance of alternative political traditions that have cultivated political agency and collective solidarity for "traditional denizens" around non-work social identities and communities. In particular, his neglect of the grassroots organising tradition overlooks how alternative social movements have sought to challenge the fundamental predicament of liberal democracy - the gap between reality and rhetoric for oppressed and devalued social groups. Only by studying concrete examples of struggles against precaritisation from below can we move beyond a liberal politics of hope to an embodied politics of collective transformation.

\section{Beyond Neo-liberal Determinism: The Limits of Anger as an Empowering Force}

One of the most compelling insights that Standing makes about the politics of the precariat concerns the changing "structures of feeling" generated by the neo-liberal economic order. Although he did not draw directly upon Raymond Williams's classic concept, Standing recognised that the consolidation of market fundamentalism in social, economic and political life corresponded to the emergence of new sets of feelings that "exert palpable pressures and set effective limits on experience and action" (Williams, 1977: 131). Not only did the destruction of stable jobs give rise to pervasive feelings of anger, anomie, anxiety and alienation among the precariat - or the four A's, as Standing puts it - but "governments killed a major source of social empathy" for working people when they dismantled the occupational guilds that "provide[d] a work-based framework by which ethics and reciprocity [a]re reproduced" (Standing, 2014: 121). As a result, twentieth-century labour unions tend to be more interested in defending the gains and privileges of the protected few than addressing the chronic insecurity, poverty and debt of the expanding precariat (Standing, 2014: 179_186).

The crude utilitarianism of the "neo-liberals" exacerbates the lack of empathy and social solidarity for the precariat. By treating the working poor, the underemployed and the unemployed as undeserving recipients of even the most basic of citizenship rights and entitlements, the precariat are denied the most basic forms of empathy and compassion. This gross denial of social justice is by no means permanent or inevitable, however. Standing predicts that the destructive tendencies of the neo-liberal project will generate the cross-class social forces needed to abolish the precariat and rebuild the Good Society - that is, a society that actively fosters rather than suppresses social relations based on empathy, compassion and solidarity in the face of deepening inequality and injustice. Towards this end, Standing (2014: 150) puts forth a Precariat Charter that seeks to "harness the anger and disillusion with older political agendas" and to foster what Czech philosopher Jan Patocka calls a "solidarity of the shocked" (Patocka, in Standing, 2014: 150).

Standing's assessment of the destructive tendencies of neo-liberalism highlights the transformative potential of affective politics. However, despite his belief that the numerical misery of the precariat will translate into a transformative politics of anger, shock, disillusionment and indignation, to what extent can we actually expect that neo-liberalism's destructive social tendencies will foment progressive political transformation? "The scourge of uncertainty", as Standing puts it, may be a spark for some and even catalyse mass mobilisation on an unprecedented global scale, as in 
the case of the Occupy movements. Yet, mass mobilisation based on collective anger is not enough to produce meaningful and ongoing social transformation, as Standing (2014: 134-5) himself points out when discussing the limits of the Occupy movement.

Empirical studies of social movement participation remind us that participation in a mass protest may be a life-changing political experience; however, such occurrences are the exception rather than the norm. Catherine Corrigall-Brown (2011: 39) finds that although most Americans have participated in a street march or public protest at some point in their lives, "only some have been fundamentally transformed by their participation and become committed, lifelong activists". In other words, shock, anger and disillusionment may compel someone to take to the streets in defiance of the status quo, but such feelings do not sustain ongoing participation in oppositional movements, especially in the face of intensified opposition from ruling elites. In addition, if one considers the range of negative feelings associated with neo-liberalism, it is just as likely that dominant social groups will express reactionary sentiments in defence of hegemonic power relations such as anti-immigrant hostility, xenophobia, religious intolerance and homophobia, instead of empathy and solidarity for the socially vulnerable and marginalised (Ahmed, 2004).

It would also be a mistake to assume a direct correspondence in the structures of feeling associated with neo-liberalism as a set of destructive and disabling political forces and the structures of feeling associated with exercising political agency from below. In his final opus, Injustice: The Social Bases for Obedience and Revolt, Barrington Moore (1978) reminds us that human beings have an inordinate capacity to endure social suffering and exploitation, especially in the presence of persons with greater authority and status. John Gaventa (1982) adds that if the oppressed and powerless seem to exhibit passivity and quiescence, as in the case of rural Appalachians, such circumstances are more likely the effect of power and the capacity of ruling authorities to suppress and sanction the expression of anger and indignation from subordinated groups. Standing recognises the impediments that the precariat confronts in exercising voice and agency; however, he finds faith in the liberal creed and the eventual tipping point that the injustice of the neo-liberal order and mass precaritisation will exert on the collective consciousness of society. While such faith may inspire some, it grossly underestimates the material conditions and asymmetrical power relations that undergird unequal class and status orders, whether defined by economic wealth and ownership structures, patriarchal systems, entrenched ethno-racial hierarchies or exclusionary citizenship regimes.

\section{Correcting Historical Amnesia: The Problem of Racial and National Oppression in Celebrating Industrial Unionism}

Standing's hopeful optimism of the "solidarity of the shocked" stands in stark contrast to his deep pessimism about the destruction of solidaristic traditions under industrial unionism. Standing (2014: 1, 22) repeatedly asserts that precarious work has stripped working people of the "old norms of labour and working classes" and the "code of ethics, feasible lifetime trajectories and communities of practice" associated with them. In this vacuum is only the frustration, alienation, anxiety and anomic despair that overwhelms people working in jobs that are low-paid, fragmented and excluded from basic labour protections. However, as the occupational and associational communities of the past industrial order are dismantled, are the precariat really left with no other sources of social esteem and social solidarity? Without a clear occupational narrative guiding their sense of self-worth 
and future aspirations, are the precariat really left with nothing else but their own malaise?

Surely, labour unions have generated indispensable sources of reciprocity and solidarity for working people throughout the history of industrial capitalism. However, they have also served as major sources of social exclusion and discrimination, particularly in the lives of women, immigrants, people of colour, colonised peoples, workers in the Third World, and other socially marginalised groups (Bonacich, 1972; Arrighi, 1990; Nakano Glenn, 2002). For example, even labour movements considered racially inclusive such as the late nineteenth-century Knights of Labor in the United States, which embraced black workers as members (albeit in racially segregated local assemblies), closed its organisational ranks to Chinese immigrant workers whom they vilified as morally degraded and culturally unassimilable (Gerteis, 2007: 62-67). Recognising the exclusionary histories of organised labour does not negate their significance for generations of workers and their families, including in the present moment as contemporary union histories redirect their organisational vision and resources toward "organising the unorganised" (Clawson, 2003; Fantasia and Voss, 2004; Milkman, 2006; Chun, 2009). But, it does require that we adopt a more sophisticated analytical lens when evaluating the relationship between neo-liberalism and precarity, especially for the subset of the precariat that Standing describes as "traditional denizens".

The historical record demonstrates that the social conditions of precarity long precede the corrosive and dehumanising effects of contemporary neo-liberal regimes. White settler colonialism, racial apartheid, patriarchy, sexism and other systems of state domination operate simultaneously with global capitalism to exploit, hierarchise and subjugate. Whether talking about the segmented labour markets of industrialising countries in the nineteenth and twentieth centuries or the "geographies of centrality and marginality" in post-Fordist global cities (Sassen, 1998), the chronic insecurity, poverty, deprivation and discrimination of precarious work is historically linked to the institutional subordination of groups designated as racial Others and national outsiders.

Let us take the example of migrant farmworkers, primarily from Jamaica and Mexico, who work on Canadian farms through guest worker programmes such as the Seasonal Agricultural Workers Program (SAWP) and the Stream for Lower-Skilled Occupations under the federal Temporary Foreign Worker Program (TFWP). If migrant farmworkers are denied the right - either through contractual or non-contractual mechanisms - to change employers, access unemployment insurance, migrate with their families (even on a temporary basis), pursue romantic relationships or join a labour union, the creation of neo-liberal labour migration programmes only partially explains their denizenship. In her study of changing Canadian immigration policy, Nandita Sharma (2006) argues that the growth of the temporary migrant worker population in Canada is rooted in technologies of governance used by white settler colonial nations to legitimate the creation of unequal citizenship regimes and the deprivation of basic rights to non-citizen migrants. Referencing parliamentary debates that took place in the early 1970s about the increased pressures that global economic competition places on the Canadian national economy, Sharma illustrates how racial logics about the natural predisposition of workers from the Caribbean and Mexico to working in harsh weather conditions and doing back-breaking agricultural work - as well as their inherent satisfaction as workers from poor countries at earning Canadian wages - justified the legalisation of indentured labour systems in a liberal democratic polity like Canada.

Such racist and nationalist logics continue to be at work today with the expansion of the TFWP, which is touted as a "win-win" programme for Canadian businesses that demand relief for "labour shortages" and workers from the Global South in search of jobs and upward mobility. In 
2013, over 100000 temporary foreign workers entered Canada in a range of sectors, including agriculture, domestic care work, hospitality, mining and construction - a 400 per cent increase since the federal programme was established in 2002 (CIC, 2014). A large majority of migrant workers are from the Philippines, where the historical legacies of colonialism, imperialism, US militarism, authoritarian development and neo-liberal structural adjustment have created a global supply of "migrants for export", promoted by a labour-brokering Philippine state (Rodriguez, 2010). Migrant workers from the Philippines not only comprise the largest proportion of Canada's live-in caregiver workforce, but they also make up the lion's share of the new workforce in fast food enterprises, retail and hospitality. For example, for temporary foreign workers recruited to work at Tim Hortons, a Canadian-based global fast food chain, the promise of a path to Canadian citizenship operates as a powerful disciplining force for migrant workers who consent to unpaid wages, abusive treatment and contractual violations while employed under "foreign worker" visas (Polanco, 2016).

\section{Beyond Work and the Workplace: Identity, Community and Empowering the Oppressed}

A Precariat Charter is certainly not blind to the exploitation, discrimination and dehumanisation of migrant workers. Standing resolutely denounces rising anti-immigrant sentiment that demonises migrant workers as "illegal, dirty, alien, terrorists" and calls for measures to curb labour export regimes (Article 11). He also demands that migrants be treated as "labour market equals" (Article 14) who deserve access to basic public health and welfare benefits (Article 15) (Standing, 2014: 105, 197-212). However, when he evaluates the efforts of new collective entities that have made similar demands and waged public campaigns towards such ends - such as immigrant worker centres, domestic workers' cooperatives, taxi drivers' alliances and day labourer networks - Standing (2014: 187-189) underplays their relevance, with the exception of the Self-Employed Women's Association (SEWA) in India. Since these "quasi-unions", as he puts it, cannot "control ports of entry" or exercise traditional forms of structural power, "they can be undercut" by "desperate individuals [who] will work for less than they demand" (Standing, 2014: 187).

Part of his unease in affording these new associational entities greater value and significance may be attributed to the fact that Standing provides little to no discussion of the historic role that immigrant rights groups, racial justice movements and other identity-based movements have played in supporting the struggles of "traditional denizens" during the exclusionary era of industrial unionism. For oppressed social groups, people's identities - as women, as immigrants and as members of racially and ethnically subordinated groups, rather than as members of an occupation or union - have constituted powerful sources of resistance and collective solidarity against employment-based poverty and discriminatory citizenship regimes. The Black civil rights movement in the 1960s, which exposed the fundamental contradiction between American democracy and American racism, "politicised" other people of colour, including Asian Americans and Hispanics or Latinos, to form solidaristic identities and pan-ethnic organisations based on a shared experience of racism and discrimination (Fujino, 2005; Pulido, 2006). While many accounts characterise such identity-based movements as devoid of class politics, Laura Pulido (2006: 7) reminds us that groups such as the Center for Autonomous Social Action (CASA) in the Chicano community, which was part of a Third World Left movement, explicitly linked issues around work and economic selfdetermination to racism and migrant worker exploitation in ways that pushed the United Farm 
Workers (UFW) to reframe their understanding of immigrant workers from a "problem" to a matter of racial justice and liberation.

My research on the struggles of informally and precariously employed in South Korea and the United States and, more recently, in Canada also reveals that social movement legacies cultivate crucial symbolic resources for seemingly powerless groups of workers that are rooted, not solely in work and the workplace, but also in people's social identities and communities. In the US, revitalised unions organising immigrant workers in the 1990s and beyond actively draw upon the strategic repertoires, moral vocabularies and even the actual people who worked as activists and organisers during the 1960s and 1970s civil rights and migrant farmworkers' movements to challenge the intensification of employment precarity for immigrant workers in low-paid, socially devalued jobs. In South Korea, the 1970s minjung people's movements and the 1980s-1990s student and women workers' movements played a similar role in the aftermath of the 1997-1998 Asian debt crisis by linking struggles against economic precaritisation with historical movements against authoritarian labour repression. In both countries, these alternative movement legacies were crucial in waging classification struggles that broadened conceptions of "work" and "workers" to include atypical groups, including in-home elder care workers and golf caddies, misclassified as "independent contractors" (Chun, 2009). Such examples highlight that recognising certain segments of the precariat as legitimate workers entitled to basic labour rights and protections - a key component of the Precariat Charter's first article - have directly appealed to the mobilising power of non-work identities and communities.

In Canada, there are fewer cases of immigrant workers organising, but they too are drawing on the legacy of identity-based social movements to organise precarious workers contending with intersecting forms of oppression. The transnational resonance and adaptation of Vancouver's "living wage movement" by the Hospital Employees Union (HEU), for example, is one recent example. When over 8000 hospital support services workers lost their jobs in the context of state-authorised public sector restructuring and privatisation, the HEU adapted the "community unionism" of London's Living Wage campaign to reorganise the predominantly immigrant women workforce in the laundry, housekeeping and food services departments of Vancouver's hospitals and long-term health care facilities. A key aspect of this struggle was the emotionally charged social justice unionism of HEU, which has a long history as a feminist union that has fought for and secured gender pay equity for socially marginalised workers employed on the bottom rungs of the health care industry (Chun, 2016a).

These cases highlight that the dismantling of occupational and industrial communities of the past does not create a vacuum for solidaristic action and progressive political praxis. By affirming and validating the struggles of oppressed groups over time and place, social movements create and nurture critical communities of resistance, as bel hooks (1989) puts it, that can be mobilised and activated to support oppositional struggles when they occur among different constituents and in different times and places. This does not mean that different social groups have a universal experience of oppression, be it class or racial oppression. "The very sense of sameness that succeeds in building organic solidarity can cut off aggrieved groups from one another, occlude the systemic origins of their problems, and pit them against one another by connecting inclusion for some with exclusion for others", George Lipsitz (2004: 6) astutely reminds us. However, by recognising how social identities operate as a modality through which oppression is experienced, identity-based movements can expose how the process of social subordination creates similar experiences of 
economic impoverishment and discrimination. These critical communities of resistance create an historical record - an imprint of sorts - of how subordinated social identities can be forces for progressive, rather than reactionary, social change.

\section{The Grassroots Organising Tradition: Exposing the Contradictions of Liberal Democracy}

The policies and institutional changes outlined in A Precariat Charter represent Standing's attempt to put forward a "framework for action" (Standing, 2014: xi). It is both programmatic and symbolic. Policies such as a guaranteed basic income would ensure that every person's basic material needs are covered, without conditions and regardless of one's employment status or education level. A guaranteed basic income would also have symbolic benefits for migrants and other excluded social minority groups. Standing (2014: 387) explains, "For them, even if they had to wait, a basic income would amount to an assertion that they are members of society, with an economic right that would be the basis of citizenship, promoting involvement in the agora (commons) and in the life of the polis (community)". Yet, such policies, however ambitious in scope and scale, do not adequately address the inherent paradox of liberal democracy when it comes to the many socially excluded groups that make up the precariat - namely, the denial of basic citizenship rights and cultural belonging to those deemed to be the unassimilable "Other" (Lowe, 1996). In other words, progressive policies are still policies that must be carried out and enforced in actual practice. And the historical record as well as contemporary struggles remind us that progressive economic policies can all too quickly become absorbed into the exclusionary logic of liberal democracy for people cast outside the moral fabric of the national polity, be they labelled "radical communists", "inscrutable Asians", "illegal aliens" or "violent terrorists".

The grassroots organising tradition has long understood the symbolic and material violence of liberal democracy's exclusions. The 1960s African-American civil rights movement and the subsequent Black Power movement rejected the lawful and de facto oppression of blacks in the economic, political and social realms. Yet an oft-forgotten part of this movement is the legacy of leaders such as Ella Baker, Septima Clark and Myles Horton who pioneered the movement's grassroots organising tradition which emphasised the importance of empowering the disempowered as a key vehicle for radical democratic transformation (Payne [1995] 2007). Ella Baker, in particular, warned against placing blind faith in the political will of charismatic social movement leaders who were all too easily co-optable by ruling elites. In order for blacks to be genuinely liberated from racist and oppressive power structures, Baker argued that they needed to understand their own value and strength as well as "their potential power and how to use it" (Payne, 1989: 898). The Black Power moment of the 1960s and 1970s and the Third World left movements they inspired further emphasised the political necessity of grassroots organising and empowerment. As Laura Pulido explains,

Among dominated communities, fundamental change does not occur through the ballet box, or even through mass uprisings, although both can play important roles. Rather, it centers on producing a shift in consciousness - an alternative vision of what the world might look like, an expanded sense of personal efficacy (often called empowerment), and a clear set of demands and on systematically mobilizing (Pulido, 2006: 31). 
This focus on movement processes and grassroots organising opens up an empirical black box when it comes to the affective politics of the precariat. Empirical studies of social movement participation underscore that political empowerment - understood as the willingness to stand up to power in high-risk situations and participate in ongoing struggles for social change - has more to do with participating in the process of political struggle than just benefitting from the outcome (Polletta, 2002; Corrigall-Brown, 2011). My research on the grassroots leadership model of Asian Immigrant Women Advocates (AIWA) underscores the importance of building political agency and movement leadership to empower some of the most unlikely groups, including monolingual Chinese immigrant women who live and work in ethnic urban enclaves as garment seamstresses, electronics assemblers, hotel room cleaners and in-home elder care workers (Chun, Shin and Lipsitz, 2013; Chun, 2016b). Investment in grassroots organising generates feelings of self-confidence and self-worth among people who never thought they could stand up to power. It strengthens associational bonds between movement participants and organisers in the face of conflict and opposition, and it creates horizontal and relational contexts that give people a greater stake in striving to transform exclusionary power structures through collective solidarity and change-making.

\section{Conclusion}

This essay has sought to re-centre the lives of women, immigrants and people of colour in assessing the transformative potential of the affective politics of the precariat. In doing so, it has challenged fundamental assumptions about the social conditions that promote and suppress systemic change. This includes the notion that neo-liberalism is the source of making and unmaking the precariat, as well as misguided nostalgia about the lost solidarity intrinsic to the era of industrial unionism. By showing how social identities based on race, migrant status and other axes of social domination have promoted solidaristic identities and communities, I have emphasised the salience of alternative histories of resistance and solidarity for the socially marginalised and excluded, especially the grassroots organising tradition. While my examples, which are drawn primarily upon the experiences of racialised groups in the United States, may not apply as neatly in contexts with different histories of colonialism and capitalism, they highlight the necessity of rooting our understanding of the transformational politics of the precariat in the lived experiences and social histories of one segment

of the precariat - immigrants and members of subordinated racial-ethnic groups.

\section{REFERENCES}

Agarwala, R. (2013) Informal Labor, Formal Politics, and Dignified Discontent in India. New York: Cambridge University Press.

Ahmed, S. (2004) Affective Economies. Social Text, 22(2): 117-139.

Anner, M. (2011) Solidarity Transformed: Labor Responses to Globalization and Crisis in Latin America. Ithaca, NY: Cornell University Press.

Arrighi, G. (1990) Marxist Century, American Century: The Making and Remaking of the World Labour Movement. New Left Review, 179 (January-February): 29-63. 
Bonacich, E. (1972) A Theory of Ethnic Antagonism: The Split Labor Market. American Sociological Review, 37(5): 547-559.

Burawoy, M. (2010) From Polanyi to Pollyanna: The False Optimism of Global Labor Studies. Global Labour Journal, 1(2): 301-313.

Clawson, D. (2003) The Next Upsurge: Labor and New Social Movements. Ithaca, NY: Cornell University Press.

Chun, J.J. (2009) Organizing at the Margins: The Symbolic Politics of Labor in South Korea and the United States. Ithaca, NY: Cornell University Press.

Chun, J.J. (2016a) Organizing Across Divides: Union Challenges to Precarious Work in Vancouver's Privatized Health Care Sector. Progress in Development Studies, 16(2): 173-188.

Chun, J.J. (2016b) Building Political Agency and Movement Leadership: The Grassroots Organizing Model of Asian Immigrant Women Advocates. Citizenship Studies, 20(3-4): 379-395. Available online at http://dx.doi.org/10.1080/13621025.2016.1158353.

Chun, J.J., G. Lipsitz, and Y. Shin (2013) Intersectionality as a Social Movement Strategy: Asian Immigrant Women Advocates. Signs, 38(4): 917-940.

Citizenship and Immigration Canada (CIC) (2014) Temporary Foreign Worker Program Work Permit Holders with a Valid Permit on December 31 ${ }^{\text {st }}$ by Gender and Age, 1994 to 2013. Available online at http://www.cic.gc.ca/english/resources/statistics/facts2013/temporary/11.asp.

Corrigall-Brown, C. (2011) Patterns of Protest: Trajectories of Participation in Social Movements. Stanford, CA: Stanford University Press.

Evans, P. (2010) Is it Labor's Turn to Globalize? Twenty-first Century Opportunities and Strategic Responses. Global Labour Journal, 1(3): 352-379.

Fantasia, R. and K. Voss (2004) Hard Work: Remaking the American Labor Movement. Berkeley and Los Angeles: University of California Press.

Fine, J. (2006) Worker Centers: Organizing Communities at the Edge of the Dream. Ithaca, NY: Cornell University Press.

Fujino, D.C. (2005) Heartbeat of Struggle: The Revolutionary Life of Yuri Kochiyama. Minneapolis, MN: University of Minnesota Press.

Gaventa, J. (1982) Power and Powerlessness: Quiescence and Rebellion in an Appalachian Valley. Urbana, IL: University of Illinois Press.

Gerteis, J. (2007) Class and the Color Line: Interracial Class Coalition in the Knights of Labor and the Populist Movement. Durham, NC: Duke University Press.

hooks, b. (1989) Teaching to Transgress: Education as the Practice of Freedom. New York, NY: Routledge.

Lipsitz, G. (2004) Solidarities of Sameness and the Dynamics of Difference. In Labor Versus Empire: Race, Gender, and Migration, edited by G.G. Gonzalez. Abingdon, UK: Psychology Press.

Lowe, L. (1996) Immigrant Acts: On Asian American Cultural Politics. Durham, NC: Duke University Press.

McCallum, J.K. (2013) Global Unions, Local Power: The New Spirit of Transnational Labor Organizing. Ithaca, NY: Cornell University Press. 
Milkman, R. (2006) L.A. Story: Immigrant Workers and the Future of the U.S. Labor Movement. New York, N.Y: Russell Sage Foundation.

Moore, B. (1978) Injustice: The Social Bases of Obedience and Revolt. Basingstoke, UK: Palgrave Macmillan.

Nakano Glenn, E. (2009) Unequal Freedom: How Race and Gender Shaped American Citizenship and Labor. Cambridge, MS: Harvard University Press.

Paret, M. (2013) Precarious Labor Politics: Unions and the Struggles of the Insecure Working Class in the USA and South Africa. Critical Sociology, 0896920513483149. doi:10.1177/0896920513483149.

Payne, C.M. (1989) Ella Baker and Models of Social Change. Signs, 14(4): 885-899.

Payne, C.M. ([1995] 2007). I've Got the Light of Freedom: The Organizing Tradition and the Mississippi Freedom Struggle. Berkeley: University of California Press.

Polanco, G. (2016) Consent Behind the Counter: Aspiring Citizens and Labour Control under Precarious (Im)migration Schemes. Third World Quarterly, doi: 10.1080/01436597.2015.1129892.

Poletta, F. (2002) Freedom is an Endless Meeting: Democracy in American Social Movements. Chicago, IL: University of Chicago Press.

Pulido, L. (2006) Black, Brown, Yellow, and Left: Radical Activism in Los Angeles. Berkeley: University of California Press.

Rodriguez, R.M. (2010) Migrants for Export: How the Philippine State Brokers Labor to the World. Minneapolis: University of Minnesota Press.

Sassen, S. (1998) Globalization and its Discontents. New York: The New Press.

Seidman, G.W. (2007) Beyond the Boycott: Labor Rights, Human Rights, and Transnational Activism. New York: Russell Sage Foundation Publications.

Sharma, N. (2006) Home Economics: Nationalism and the Making of "Migrant Workers" in Canada. Toronto: University of Toronto Press.

Standing, G. (2011) The Precariat: The New Dangerous Class. London: Bloomsbury Academic.

Standing, G. (2014) A Precariat Charter: From Denizens to Citizens. London: Bloomsbury Academic.

Von Holdt, K. and E. Webster (2008) Organising on the Periphery: New Sources of Power in the South African Workplace. Employee Relations, 30(4): 333-354.

Waterman, P. (1999) The New Social Unionism: A New Union Model for a New World Order. In Labour Worldwide in the Era of Globalization: Alternative Union Models in the New World Order, edited by Ronaldo Munck and Peter Waterman. London: Macmillan.

Williams, R. (1977) Marxism and Language. Oxford: Oxford University Press.

\section{BIOGRAPHICAL NOTE}

Jennifer Jihye Chun is Associate Professor in Sociology and Director of the Centre for the Study of Korea at the University of Toronto. Her research explores the changing world of work, gender and politics through a comparative historical and critical ethnographic lens. She is the author of 
Organizing at the Margins: The Symbolic Politics of Labor in South Korea and the United States (Cornell University Press, 2009). Her scholarly articles have appeared in Citizenship Studies, Critical Sociology, Journal of Korean Studies, Positions: Journal of East Asia Critique, Progress in Development Studies, Signs: Journal of Women in Culture and Society, Third World Quarterly, and Work and Occupations. Currently, she is engaged in research collaborations on protest cultures in South Korea, immigrant women workers and community organising in California's home care sector, and global comparative approaches to studying informal and precarious worker organising. [Email: ji.chun@utoronto.ca] 